\title{
Electrochemical Characterisation of SOFC Anodes
}

Ramos, Tania; Mogensen, Mogens Bjerg

Published in:

Meeting Abstracts - Electrochemical Society

Publication date:

2009

Document Version

Publisher's PDF, also known as Version of record

Link back to DTU Orbit

Citation (APA):

Ramos, T., \& Mogensen, M. B. (2009). Electrochemical Characterisation of SOFC Anodes. In Meeting Abstracts - Electrochemical Society (pp. Abstract 1399). The Electrochemical Society.

\section{General rights}

Copyright and moral rights for the publications made accessible in the public portal are retained by the authors and/or other copyright owners and it is a condition of accessing publications that users recognise and abide by the legal requirements associated with these rights.

- Users may download and print one copy of any publication from the public portal for the purpose of private study or research.

- You may not further distribute the material or use it for any profit-making activity or commercial gain

- You may freely distribute the URL identifying the publication in the public portal

If you believe that this document breaches copyright please contact us providing details, and we will remove access to the work immediately and investigate your claim. 


\section{Electrochemical characterisation of SOFC anodes T. Ramos and M. Mogensen \\ Fuel Cells and Solid State Chemistry Division \\ Risø National Laboratory - DTU \\ P.O. Box 49, DK - 4000 Roskilde, Denmark}

To assist optimisation and gain further insight on the behaviour of each cell component, it is usually necessary to break down and assign the losses into the various components. However, thin electrolyte cells cannot be used to measure anode and cathode losses separately using a reference electrode [1]. Symmetrical cells tests, associated with electrochemical impedance spectroscopy (EIS), can provide an elegant alternative for evaluation of individual electrode performance and further understanding of the processes involved, as well as assisting full cell impedance spectra deconvolution

One issue raised when evaluating the performance of a single electrode by the use of symmetric cells, such as the common Ni/YSZ cermet SOFC anode, lies in the different manufacturing processes used for the production of symmetric cells, which usually hinders direct comparison with the electrode behaviour in a full cell due to different microstructures and impurity levels $[2,3]$. The other issue arises from the interpretation of the impedance spectra, as the number and nature of the physical processes are usually not known, with interpretations differing for similar electrochemical systems $[4,5]$.

In order to minimise differences in microstructure and amount of impurities between symmetrical cells and full cells with Ni/Sc-doped YSZ (ScYSZ) based anodes, investigations of anode cermets were performed by EIS using three different types of fully tape-casted symmetrical cells. The different types used can be seen in Figure 1.
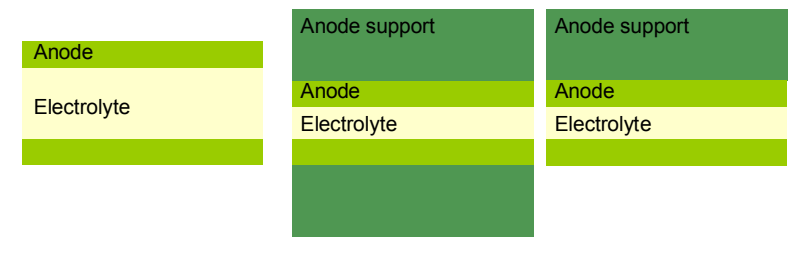

Type
Figure 1: Different types of symmetric cells with $\mathrm{Ni} / \mathrm{ScYSZ}$ anodes tested in this work.

All cells contained $\mathrm{Ni} / \mathrm{ScYSZ}$ anodes, $\mathrm{Ni} / \mathrm{YSZ}$ anode supports and ScYSZ electrolytes, with Type I corresponding to the more common thick electrolyte and Type II and III with thin electrolytes and two or one anode support, respectively. $6 \mathrm{~mm}$ x $6 \mathrm{~mm}$ sintered pieces were tested in a special designed rig. The cells were heated up in air, reduced at $1000{ }^{\circ} \mathrm{C}$ and then tested in $\mathrm{H}_{2}$ atmospheres, with varying contents of $\mathrm{H}_{2} \mathrm{O}$, between 850 and $6500^{\circ} \mathrm{C}$.

So far, interpretation of impedance spectra has been mostly based on the complex nonlinear least-squares (CNLS) approximation to a priori established model represented by the equivalent circuit. However, in this work we combine CNLS with a pre-identification method based on the distribution function of relaxation times (DRT), which enables the separation of contributing processes with different time constants directly from the impedance data $[5,6]$.
Figure 2 compares the distribution of relaxation times for a cell of type I and II at $750{ }^{\circ} \mathrm{C}, 97 \% \mathrm{H}_{2}+3 \%$ $\mathrm{H}_{2} \mathrm{O}$. The differences between them are clear and seem to indicate the presence of at least four distinct contributions to the overall impedance, in both cases.

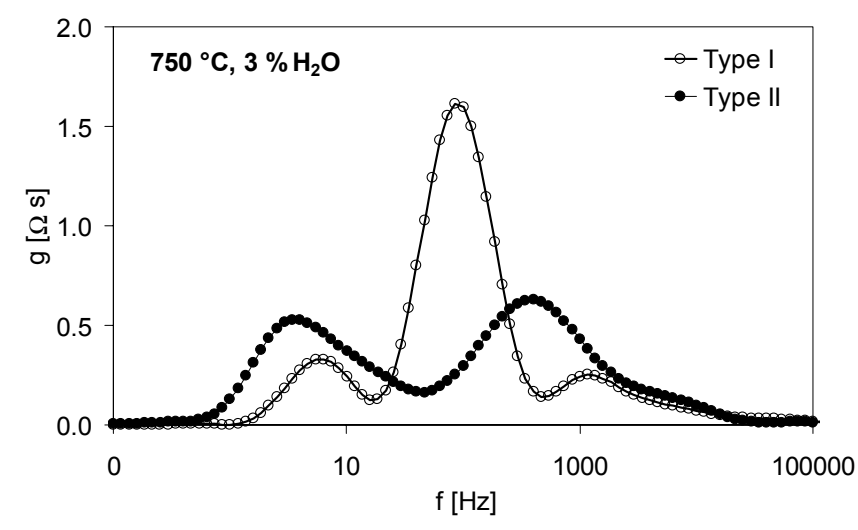

Figure 2: DRT of symmetrical cells with $\mathrm{Ni} / \mathrm{ScYSZ}$ anodes of type I (electrolyte supported) and type II (anode supported).

In addition, suitable changes in testing parameters, such as temperature and water content, were also performed to gain further information on the total number of contributions, as well as on their individual dependencies. This extra knowledge can also prove useful to determine which physicochemical process corresponds to each feature seen in the impedance spectra. So being, a suitable starting equivalent circuit for CNLS fitting would be $\mathrm{LR}(\mathrm{RQ})(\mathrm{RQ})(\mathrm{RQ})(\mathrm{RQ})$.

This combined DRT/CNLS approach will be used for the deconvolution and fitting of the obtained impedance spectra and correlated, whenever possible, to the microstructural features of the tested anodes. The results will be viewed in the light of other published results, in an attempt to increase the knowledge on the electrochemical behaviour of Ni-based SOFC anodes.

\section{Acknowledgements}

The authors wish to thank Mrs. K. Brodersen and Dr. N. Bonanos. Financial support from Energinet.dk through PSO project no. 7124 SOFC R\&D is gratefully acknowledged.

[1] M. Mogensen and P. V. Hendriksen in High Temperature Solid Oxide Fuel Cells, S. C. Singhal and K. Kendall, Editors, Chapter 10, p. 261, Elsevier Ltd., (2003)

[2] M. Mogensen and S. Skaarup, Solid State Ionics, 86/87 1151 (1996)

[3] M. de Ridder, A.G.J. Vervoot, R.G. van Welzenis and H.H. Brongersma, Solid State Ionics, 156, 255 (2003)

[4] R. Barford, M. Mogensen, T. Klemenso, A. Hagen, YL Liu, P. V. Hendriksen, J. Electrochem. Soc., 154, B371 (2007)

[5] V. Soon, A. Leonide, and E. Ivers-Tiffée, J. Electrochem. Soc., 155, B675 (2008)

[6] H. Schichlein, A.C. Müller, M. Voigts, A. Krügel and E. Ivers-Tifée, J. Applied Electrochem., 32, 875 (2002) 